\title{
Vitamin D status in Irish infants
}

\section{Authors :}

Aoife Carroll ${ }^{1,2}$,

Chike Onwuneme ${ }^{1,2}$,

Malachi McKenna ${ }^{2,3}$,

Eleanor J Molloy ${ }^{4,5}$,

Nuala Murphy ${ }^{1,2}$

\section{Authors Note:}

${ }^{1}$ Dept of Endocrinology, Children's University Hospital, Temple Street, Dublin 1, Ireland

${ }^{2}$ UCD School of Medicine and Medical Sciences, University College Dublin, Co. Dublin, Ireland

${ }^{3}$ Dept of Endocrinology and Metabolic Lab, St Vincent's University Hospital, Dublin 4, Ireland

${ }^{4}$ Coombe Women and Infant's University Hospital, Dublin 8, Ireland

${ }^{5}$ Dept of Paediatrics, Trinity College Dublin, Adelaide and Meath Hospital, Tallaght, Dublin 24, Ireland

\section{Corresponding author information:}

Dr. Aoife Carroll,

Department of Endocrinology,

Children's University Hospital, T

emple Street, Dublin 1, Ireland;

aoifecar@gmail.com;

Telephone 0035318784545;

Fax +35318921781

\section{$\underline{\text { Abstract }}$}

Vitamin D is essential for good bone health particularly during infancy, a time of rapid growth. Given Irelands northerly latitude, Irish children are at risk of suboptimal vitamin D levels. The aim of our study was to describe the vitamin D status of a group of Irish infants and identify factors predictive of vitamin D status. A cross sectional study was undertaken over a 12 month period in a single paediatric tertiary referral centre in Dublin. Fifty four healthy term infants ( $<1$ year of age) attending a single hospital for minor medical or surgical procedures were recruited. All patients had measurement of serum 25-hydroxyvitamin D (25OHD), parathyroid hormone (PTH) and a bone profile. A questionnaire detailing vitamin D intake from diet, vitamin $\mathrm{D}$ supplementation and sun exposure was completed on behalf of each participant. The mean (SD) for serum $25 \mathrm{OHD}$ was 80.8 (34.4) nmol/L and almost $80 \%$ of infants had $25 \mathrm{OHD}$ levels $>50 \mathrm{nmol} / \mathrm{L}$. Lower serum 25OHD levels were seen in the following: breastfed infants, infants with formula consumption of $<500 \mathrm{ml}$ per day, darker skin and no vitamin D supplementation. In our study, most infants have 25OHD levels in the range for optimal skeletal development, above 50 $\mathrm{nmol} / \mathrm{L}$, but important risk factors for suboptimal serum 25OHD levels have been identified and will aid in identifying those infants most at risk.

Key words: Ireland, Vitamin D, Infant, 25-OH vitamin D 


\section{Medical Research Archives. Volume 5, Issue 6.June Issue}

Vitamin D status in Irish infants.

\section{Introduction}

Infancy is a time of rapid linear growth and vitamin D is essential for good bone health as it plays a fundamental role in bone metabolism and calcium homeostasis. Severe deficiency manifests itself clinically with rickets (1). Infants are at particular risk of low serum 25 hydroxyvitamin D (25OHD) levels in comparison to older children or adults. Firstly, it is recommended that they avoid direct exposure to sunlight, the major endogenous source of cholecalciferol (vitamin $\mathrm{D}_{3}$ ) (2) Secondly, the few natural food sources of vitamin D, such as oily fish and eggs, are not commonly part of infant diets. Finally, while formula milk is fortified with vitamin D and contains on average $480 \mathrm{IU} / \mathrm{L}$ of vitamin $\mathrm{D}_{3}$, the vitamin $\mathrm{D}$ content of breast milk is lower (25-78 IU/L), even when lactating mothers are supplemented with vitamin D daily $(3,4)$.

A Cochrane review from 2006 agreed that vitamin D supplementation of infants and toddlers was appropriate as a measure to prevent nutritional rickets (5). Both the American Academy of Pediatrics (AAP) and the Lawson Wilkins Pediatric Endocrine Society (LWS) recommend vitamin D supplementation of 400 IU per day for all infants, unless they are consuming more than 1 litre of fortified formula milk per day $(6,7)$. The Institute of Medicine (IOM) also recommends an adequate intake of $400 \mathrm{IU}$ of vitamin D per day in infancy (8). Most European countries have adopted similar policies for vitamin D supplementation in infancy, with the majority recommending $400 \mathrm{IU}$ of vitamin D once a day (9).
In June 2010, a national policy recommending supplementation of all Irish infants from birth to 12 months with 200 IU daily of vitamin $\mathrm{D}_{3}$ irrespective of whether breastfeeding or formula feeding was implemented $(9,10)$. While this policy was in keeping with international recommendations, no data describing the vitamin $\mathrm{D}$ status of Irish term infants was available prior to its introduction. A study of preterm Irish infants has since found that up to $78 \%$ of them had 25OHD levels below $50 \mathrm{nmol} / \mathrm{L}$ (11).

Vitamin D has a number of extraskeletal roles; vitamin D receptors are found in many tissues and cells of the body that are unrelated to calcium and bone metabolism (12). Vitamin D is an immunomodulator and supplementation in infancy has been associated with a reduced incidence of developing type 1 diabetes mellitus, an autoimmune condition (13, 14). Increased susceptibility to infection at lower serum 25OHD levels has been reported but a randomised controlled trial in young children has failed to support this finding (15-18).

The optimal 25OHD level for skeletal and extraskeletal health remains a topic for debate. Position statements from two paediatric bone groups have recommended that the target 25OHD level for optimal bone health in infants, children and adolescents is $\geq 50 \mathrm{nmol} / \mathrm{L}(19,20)$. It is generally accepted that vitamin $\mathrm{D}$ deficient rickets, in the setting of a normal calcium intake, does not occur if the serum $25 \mathrm{OHD}$ level is above $30 \mathrm{nmol} / \mathrm{L}$ and often only at levels below $12.5 \mathrm{nmol} / \mathrm{L}(1,20,21)$.

Supplementing Irish infants with vitamin D should optimise bone health and avoid privational 
Vitamin D status in Irish infants.

rickets. Supplemented infants may also benefit from possible extraskeletal benefits of vitamin $\mathrm{D}$ in the short and long term. The aim of this study was to describe the vitamin D status of a group of healthy Irish term infants and identify factors predictive of vitamin D status.

\section{Experimental methods}

\subsection{Patient group}

Ethical approval for the study was granted by the Scientific and Ethics Committee of the Children's University Hospital. Written informed parental consent was given in all cases. We performed a cross sectional study over a 12-month period from March 2010 - March 2011. We recruited healthy term infants, born in Ireland, attending the Children's University Hospital for elective surgery (26\%), medical outpatients (62\%) or the emergency department (12\%) for a minor complaint. Children with complex disorders likely to affect vitamin D intake or absorption or known metabolic bone disease were excluded. All children were having phlebotomy performed for a clinical indication.

\subsection{Questionnaire}

A questionnaire was completed on behalf of each patient enrolled in the study detailing vitamin D intake from diet, vitamin D supplementation and sun exposure. Weekly intake of vitamin D rich foods (oily fish and eggs) was documented as well as daily milk consumption and the use of formula milk. The use of vitamin D supplements and multivitamins over the previous 3 months was noted. The implementation of the national policy recommending vitamin D supplementation occurred midway through the study period. Sun exposure over the previous week was recorded, including the use of sunscreen. The ethnicity of the child was determined using the Health Service Executive Ethnic Identifier in addition to the parents' country of origin. The presence of any medical condition, use of medications and reason for attendance at hospital was documented.

\subsection{Laboratory measurements}

Whole blood $(3.5 \mathrm{ml})$ was taken in serum bottles from each patient. Serum 25OHD, PTH and a bone profile (calcium, phosphate, alkaline phosphatase, albumin and urea) were measured. Total 25OHD $\left(25 \mathrm{OHD}_{2}\right.$ and $\left.25 \mathrm{OHD}_{3}\right)$ was measured by liquid chromatography tandem mass spectrometry. The assay has an intra-assay $\mathrm{CV}$ of $5 \%$ and an inter-assay CV of 7\%. Vitamin D levels are expressed as total vitamin D. Serum PTH assay was measured using a solid-phase two-site chemiluminescent immunoassay, performed on the ImmuliteTM 2000. The assay has an intra-assay CV of $5 \%$ and an inter-assay $\mathrm{CV}$ of $4 \%$. Bone profiles were performed on the Beckman Coulter DXC 600 Analyser.

\subsection{Interpretation of vitamin D status}

Serum 25OHD levels were interpreted according to the 2011 Institute of Medicine report as follows: a serum 25OHD level below $30 \mathrm{nmol} / \mathrm{L}$ $(12 \mathrm{ng} / \mathrm{ml})$ was defined as being at increased risk of vitamin D deficiency; a level of 30-to-50 nmol/L $(12-20 \mathrm{ng} / \mathrm{ml})$ as within the range of adequacy, and $>50 \mathrm{nmol} / \mathrm{L}(20 \mathrm{ng} / \mathrm{ml})$ as sufficient. All patients with serum $25 \mathrm{OHD}<50 \mathrm{nmol} / \mathrm{L}$ were informed of 
Medical Research Archives. Volume 5, Issue 6.June Issue

Vitamin D status in Irish infants.

the result and supplementation with $200 \mathrm{IU}(5 \mu \mathrm{g})$ of vitamin $\mathrm{D}_{3}$ was recommended for 3 months along with other measures to improve vitamin D intake.

\subsection{Statistical analysis}

Results are presented as mean and standard deviation (SD) or as number and percentage. Serum 25OHD levels were normally distributed. Serum 25OHD was analysed as a continuous variable and its association with other variables was examined using independent t-tests if two groups were present and ANOVA if 3 or more groups were present. The association between serum 25OHD and indices of calcium metabolism was analysed by Pearson's correlation coefficient. The total group was divided into two categories of vitamin D status based on a 25OHD threshold of $>50 \mathrm{nmol} / \mathrm{L}$; the relationship with other categorical variables was tested by Chisquare. Significance was defined as $\mathrm{p}<0.05$. Statistical analysis was conducted using IBM SPSS Stats for Windows Version 20 (Armonk, New York).

\section{Results}

We studied 54 term infants; the median age was 0.58 years (range 0.06-0.98 years); there were 26 females and 28 males; ethnicities included white Irish, white European and Asian. The mean (SD) for serum 25OHD was 80.8 (34.4) nmol/L; $7.4 \%$ had serum $25 \mathrm{OHD}$ levels below $30 \mathrm{nmol} / \mathrm{L}$ (at-risk of vitamin $\mathrm{D}$ deficiency), $13 \%$ in the range of adequacy (30-50 nmol/L) and 79.6\% had levels above the threshold for sufficiency $(>50 \mathrm{nmol} / \mathrm{L})$. Descriptive statistics of measured bone indices (calcium, phosphate, alkaline phosphatase and parathyroid hormone $(\mathrm{PTH}))$ are shown in Table 1. Serum 25OHD levels correlated inversely with PTH $(\mathrm{r}=-0.335, \mathrm{p}=0.019)$ while calcium $(\mathrm{r}=0.342$, $\mathrm{p}=0.015$ ) showed a positive correlation with 25OHD. There was no correlation between phosphate $\quad(\mathrm{r}=0.228, \quad \mathrm{p}=0.111) \quad$ or alkaline phosphatase ( $r=-0.131, \mathrm{p}=0.363)$ and 25OHD.

Table 1: Descriptive statistics of laboratory measurements in all infants

\begin{tabular}{llll}
\hline Variable & Mean & SD & Range \\
\hline 25OHD (nmol/L) & 80.8 & 34.4 & $10.0-149.8$ \\
PTH (ng/L) & 45.2 & 145.5 & $3.0-1023.7$ \\
Calcium (mmol/L) & 2.49 & 0.11 & $2.05-2.74$ \\
Phosphate (mmol/L) & 1.95 & 0.25 & $0.84-2.43$ \\
Alk Phos (U/L) & 363 & 603 & $118-4240$ \\
\hline
\end{tabular}

Infants consuming formula milk had mean (SD) serum 25OHD levels more than double those of breastfed infants (87.5 (30.7) versus 34.6 (23.1) nmol/L, p<0.001) (Figure 1) (Table 2). 
Figure 1: Mean 25OHD levels in relation to type of feeding and use of supplements.

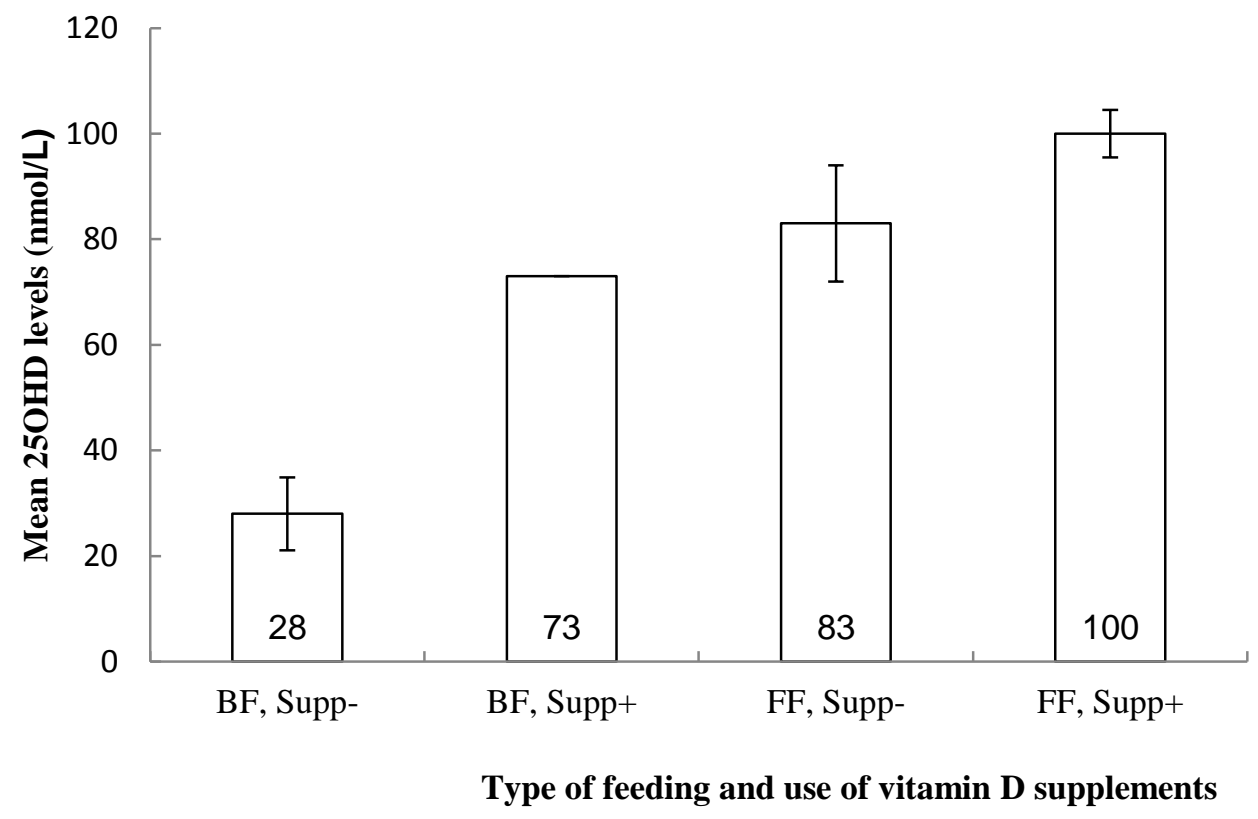

25OHD, 25-hydroxyvitamin D; BF, breast fed; FF, formula fed; Supp -, no vitamin D supplementation; Supp+, vitamin $\mathrm{D}$ supplementation.

Mean 25OHD value displayed at base of column. Standard error of the mean illustrated by error bars. No error bar in BF, Supp + as only 1 patient in that group.

Infants who consumed $\geq 500 \mathrm{ml}$ of formula milk per day had significantly higher serum $25 \mathrm{OHD}$ levels than those consuming $<500 \mathrm{ml}(\mathrm{p}=0.023)$ (Table 2). Almost 30\% of infants were receiving vitamin D supplementation and this significantly increased the mean (SD) serum 25OHD levels from 73.8 (31.3) $\mathrm{nmol} / \mathrm{L}$ in the unsupplemented group to 98.5 (39.3) $\mathrm{nmol} / \mathrm{L}$ in the supplemented group $(\mathrm{p}=0.025)$. Of the infants receiving vitamin $\mathrm{D}$ supplementation, $92 \%$ had $25 \mathrm{OHD}$ levels above 50 $\mathrm{nmol} / \mathrm{L}$. Consumption of other dietary sources of vitamin D did not significantly affect serum 25OHD levels. Ethnicity significantly affected vitamin D status. Children of Asian ethnicity had significantly lower mean 25OHD levels than white Irish or other European children $(\mathrm{p}=0.038)$. 
Medical Research Archives. Volume 5, Issue 6.June Issue

Vitamin D status in Irish infants.

Table 2: Descriptive statistics of factors associated with vitamin D status

\begin{tabular}{|c|c|c|c|c|c|c|}
\hline Factor & Characteristic & $n$ & $\%$ & Mean 25OHD & $\mathrm{SD}$ & $P$ \\
\hline All & & 54 & 100 & 80.8 & 34.4 & \\
\hline \multirow[t]{2}{*}{ Sex } & Female & 26 & 48 & 83.2 & 41.1 & 0.470 \\
\hline & Male & 28 & 52 & 76.2 & 28.5 & \\
\hline \multirow[t]{2}{*}{ Age } & $<6$ months & 24 & 44 & 72.5 & 38.1 & 0.225 \\
\hline & $\geq 6$ months & 30 & 56 & 84.6 & 32.1 & \\
\hline \multirow[t]{2}{*}{ Health insurance } & Yes & 12 & 22 & 76.2 & 28.3 & 0.708 \\
\hline & No & 42 & 78 & 80.5 & 27.5 & \\
\hline \multirow[t]{2}{*}{ Ethnicity } & Non-Asian & 43 & 83 & 84.2 & 32.0 & $0.038^{*}$ \\
\hline & Asian & 9 & 17 & 58.0 & 40.7 & \\
\hline \multirow[t]{2}{*}{ Supplements } & Yes & 14 & 29 & 98.5 & 39.3 & $0.025 *$ \\
\hline & No & 35 & 71 & 73.8 & 31.3 & \\
\hline \multirow[t]{2}{*}{ Milk type } & Breastfed & 7 & 14 & 34.6 & 23.1 & $<0.001^{*}$ \\
\hline & Formula & 44 & 86 & 87.5 & 30.7 & \\
\hline Milk intake & $<500$ & 12 & 27 & 67.0 & 28.3 & $0.023^{*}$ \\
\hline (ml/day) & $\geq 500$ & 33 & 73 & 91.2 & 32.9 & \\
\hline \multirow[t]{2}{*}{ Egg intake/wk } & Never & 10 & 20 & 77.4 & 35.0 & 0.235 \\
\hline & $<3$ & 41 & 80 & 92.1 & 33.4 & \\
\hline Oily fish & $<1$ & 41 & 82 & 79.9 & 36.3 & 0.653 \\
\hline intake/wk & $\geq 1$ & 9 & 18 & 85.1 & 29.0 & \\
\hline \multirow[t]{2}{*}{ Season } & April/Sept & 27 & 50 & 73.1 & 33.2 & 0.181 \\
\hline & Oct/Mar & 27 & 50 & 86.0 & 36.1 & \\
\hline \multirow{2}{*}{ Sunscreen use } & Yes & 15 & 40 & 86.4 & 25.9 & 0.656 \\
\hline & No & 22 & 60 & 80.7 & 44.1 & \\
\hline \multirow{2}{*}{ Sun exposure/day } & $<30$ mins & 33 & 70 & 76.9 & 37.5 & 0.234 \\
\hline & $\geq 30 \mathrm{mins}$ & 14 & 30 & 89.2 & 28.8 & \\
\hline
\end{tabular}

25OHD, 25-hydroxyvitamin D

*Mean value was different between the two groups

Vitamin D status did not change more common in the second half of the study significantly by infant age, gender, time spent period, following implementation of the national outdoors, sunscreen use or health insurance, a vitamin D supplementation policy, compared to the surrogate marker of socioeconomic status. Vitamin D status did not change significantly by season. first half $(p=0.169)$. In infants with the lowest and highest serum 25OHD levels, use of vitamin D The mean (SD) 25OHD levels for January-March, April-June, July-September and October December were 71.1 (26.7), 66.7 (28.6), 74.6 (34.6) and $94.2(38.7) \mathrm{nmol} / \mathrm{L}$, respectively. supplementation and feeding type were examined (Table 3). Those with the highest serum 25OHD levels were all formula fed while those with the lowest values were all breastfed.

There was a non-significant trend for the prevalence of vitamin D supplementation to be 
Table 3: Type of feeding type, milk volume and supplementation use in the infants with the highest and lowest 25OHD levels.

\begin{tabular}{lllll} 
Age (years) & $\begin{array}{l}25 \mathrm{OHD} \text { level } \\
(\mathrm{nmol} / \mathrm{L})\end{array}$ & Feeding type & Milk per day $(\mathrm{ml})$ & Supplementation \\
\hline & & & & \\
0.94 & 10.0 & $\mathrm{BF}$ & $\mathrm{NA}$ & No \\
0.06 & 12.6 & $\mathrm{BF}$ & $\mathrm{NA}$ & No \\
0.29 & 21.4 & $\mathrm{BF}$ & $\mathrm{NA}$ & No \\
0.06 & 34.7 & $\mathrm{BF}$ & $\mathrm{NA}$ & No \\
0.21 & 126 & $\mathrm{FF}$ & $500-1000 \mathrm{ml}$ & No \\
0.59 & 138.4 & FF & $500-1000 \mathrm{ml}$ & No \\
0.98 & 146.2 & FF & $500-1000 \mathrm{ml}$ & No \\
0.78 & 149.8 & FF & $500-1000 \mathrm{ml}$ & Yes \\
& & & & \\
\hline
\end{tabular}

25OHD, 25 hydroxyvitamin D; BF, breast fed; FF, formula fed; NA, not available

\section{Discussion}

This is the first study describing the vitamin D status of a group of healthy Irish term infants. Almost $80 \%$ of whom had serum $25 \mathrm{OHD}$ levels at or above the threshold for sufficiency $(50 \mathrm{nmol} / \mathrm{L})$ despite the fact that only one third of them were taking vitamin D supplements. The type of feeding, quantity of formula milk consumed, use of vitamin D supplements and ethnicity all had a significant effect on serum 25OHD levels.

As expected, unsupplemented breastfed infants had lower mean serum 25OHD levels than formula fed infants with or without vitamin D supplementation, in keeping with previous reports (22-24). Only one of the breastfed infants was supplemented and this infant had a serum 25OHD level of $73 \mathrm{nmol} / \mathrm{L}$. Supplementation of breastfed infants with $400 \mathrm{IU}$ of vitamin $\mathrm{D}_{3}$ has been shown to maintain 25OHD levels above $50 \mathrm{nmol} / \mathrm{L}$ without adverse events but has not been shown to be superior to 200-250 IU(25-29). In order to achieve a serum $25 \mathrm{OHD}$ level $\geq 75 \mathrm{nmol} / \mathrm{L}$, high dose vitamin D supplementation of breast fed infants has been examined (25). Vitamin $\mathrm{D}_{3}$ dosages of 400, 800, 1200 and 1600 IU have been compared; at 3 months the mean serum 25OHD levels in the 4 groups were 78, 102, 134 and $180 \mathrm{nmol} / \mathrm{L}$, respectively. The 1600 IU dosage was discontinued because most infants in this group developed elevated serum 25OHD concentrations that have been associated with hypercalcaemia. Similar serum 25OHD levels were reported in a similar study in which infants were supplemented with 250,750 or 1000 IU of vitamin $\mathrm{D}_{3}$ (30). The 2011 IOM report established a safe range above the range of adequacy from 50-125 nmol/L and set tolerable upper intake levels for infants aged 0-6 months of 1000 IU/day, and for those aged 6-12 months of $1500 \mathrm{IU} / \mathrm{day}(8)$. 


\section{Medical Research Archives. Volume 5, Issue 6.June Issue}

Vitamin D status in Irish infants.

Most infants in this study were formula fed. Breast feeding rates in Ireland are among the lowest in Europe (31) but initiatives by the health service are aiming to improve these rates $(32,33)$. Consumption of formula milk led to higher vitamin D levels as expected, given the vitamin D fortification of this product.

Four months into the 12-month study period (June 2010), the policy on vitamin D supplementation for infants in Ireland was implemented. The percentage of infants receiving vitamin D supplements increased but not significantly in the second half of the study period $(\mathrm{p}=0.169)$. This reflects the recent introduction of the policy. Poor adherence to vitamin D supplementation policies in children has been recognised in Ireland and other European countries (34-36).

We demonstrated a significant effect of ethnicity on vitamin D status. Darker skin colour is a well-recognised risk factor for vitamin D deficiency as melanin absorbs ultraviolet B photons, which reduce the endogenous production of vitamin D. In a review of 166 cases of nutritional rickets in the United States, $83 \%$ of children were described as African American or black (24). We observed no seasonal variation in serum 25OHD levels in infancy; this is not surprising as it is recommended that infants, particularly less than six months of age, are not exposed to direct sunlight and is consistent with other studies $(22,29)$.

One case of rickets was identified in an unsupplemented breastfed infant of Asian ethnicity aged 11 months. This patient had a serum 25OHD level of $10 \mathrm{nmol} / \mathrm{L}$ with calcium within the normal range $(2.40 \mathrm{mmol} / \mathrm{L})$, a low phosphate level $(0.84$ $\mathrm{mmol} / \mathrm{L})$ and a raised alkaline phosphatase (1385 U/L) and PTH (1023 ng/L).

The relatively small sample size may be seen as a limitation of this study. However, this group of patients had an equal sex distribution, included infants from across the country at various stages of infancy and had an ethnicity profile in keeping with that of the general population.

Most Irish infants had serum 25OHD levels in the target range, which is ideal for good bone health. Unsupplemented breast-fed infants and those with darker skin colour were most at risk of vitamin $\mathrm{D}$ deficiency and these at risk groups should be particularly targeted by healthcare professionals in Ireland when discussing vitamin D supplementation.

\section{Acknowledgements}

The authors thank the children and their families for their participation in this research, and the many staff at the Children's University hospital who allowed access to their patients, and assisted with recruitment, sample collection and analysis. We would particularly like to thank Ethna O' Shea for her contribution.

\subsection{Financial support}

This research was funded by Children's Fund for Health, Temple St, Dublin. Children's Fund for Health had no role in the design, analysis or writing of this article. 
Medical Research Archives. Volume 5, Issue 6.June Issue

Vitamin D status in Irish infants.

5.2 Conflict of Interest

None

Contributorship

$\mathrm{AC}$ and NM designed the study, obtained funding and ethical approval and recruited patients. AC and MJM analyzed the data. AC wrote the manuscript.

$\mathrm{CO}$ and EJM assisted with design and implementation of the study. 


\section{References}

1. Wharton B, Bishop N. Rickets. Lancet. 2003;362(9393):1389-400.

2. Section on D, Balk SJ. Ultraviolet radiation: a hazard to children and adolescents. Pediatrics. 2011;127(3):588-97.

3. Wagner CL, Hulsey TC, Fanning D, Ebeling M, Hollis BW. High-dose vitamin D3 supplementation in a cohort of breastfeeding mothers and their infants: a 6-month follow-up pilot study. Breastfeeding medicine : the official journal of the Academy of Breastfeeding Medicine. 2006;1(2):59-70.

4. Hollis BW, Roos BA, Draper HH, Lambert PW. Vitamin D and its metabolites in human and bovine milk. The Journal of nutrition. 1981;111(7):1240-8.

5. Lerch $\mathrm{C}$, Meissner T. Interventions for the prevention of nutritional rickets in term born children. Cochrane Database Syst Rev. 2007(4):CD006164.

6. Misra M, Pacaud D, Petryk A, CollettSolberg PF, Kappy M. Vitamin D deficiency in children and its management: review of current knowledge and recommendations. Pediatrics. 2008;122(2):398-417.

7. Wagner CL, Greer FR. Prevention of rickets and vitamin $\mathrm{D}$ deficiency in infants, children, and adolescents. Pediatrics. 2008;122(5):1142-52.

8. Dietary Reference Intakes for Calcium and Vitamin D. Ross AC, Taylor CL, Yaktine AL, Valle HBD, editors: The National Academies Press; 2011.
9. FSAI. Recommendations for a National Policy on Vitamin D Supplementation for Infants in Ireland 2007.

10. Members HNSGoVD. Vitamin D Supplementation for Infants in Ireland. 2010.

11. McCarthy RA, McKenna MJ, Oyefeso O, Uduma O, Murray BF, Brady JJ, et al. Vitamin D nutritional status in preterm infants and response to supplementation. The British journal of nutrition. 2013;110(1):156-63.

12. Wang Y, Zhu J, DeLuca HF. Where is the vitamin D receptor? Archives of biochemistry and biophysics. 2012;523(1):123-33.

13. Hypponen E, Laara E, Reunanen A, Jarvelin MR, Virtanen SM. Intake of vitamin D and risk of type 1 diabetes: a birth-cohort study. Lancet. 2001;358(9292):1500-3.

14. Zipitis CS, Akobeng AK. Vitamin D supplementation in early childhood and risk of type 1 diabetes: a systematic review and meta-analysis. Archives of disease in childhood. 2008;93(6):512-7. 15. Camargo CA, Jr., Ingham $\mathrm{T}$, Wickens $\mathrm{K}$, Thadhani R, Silvers KM, Epton MJ, et al. Cordblood 25-hydroxyvitamin D levels and risk of respiratory infection, wheezing, and asthma. Pediatrics. 2011;127(1):e180-7.

16. Urashima $M$, Segawa $T$, Okazaki $M$, Kurihara M, Wada Y, Ida H. Randomized trial of vitamin D supplementation to prevent seasonal influenza $A$ in schoolchildren. The American journal of clinical nutrition. 2010;91(5):1255-60. 
Vitamin D status in Irish infants.

17. Belderbos ME, Houben ML, Wilbrink B, Lentjes E, Bloemen EM, Kimpen JL, et al. Cord blood vitamin D deficiency is associated with respiratory syncytial virus bronchiolitis. Pediatrics. 2011;127(6):e1513-20.

18. Manaseki-Holland S, Maroof Z, Bruce J, Mughal MZ, Masher MI, Bhutta ZA, et al. Effect on the incidence of pneumonia of vitamin D supplementation by quarterly bolus dose to infants in Kabul: a randomised controlled superiority trial. Lancet. 2012;379(9824):1419-27.

19. Arundel P, Ahmed SF, Allgrove J, Bishop NJ, Burren CP, Jacobs B, et al. British Paediatric and Adolescent Bone Group's position statement on vitamin D deficiency. Bmj. 2012;345:e8182.

20. Paxton GA, Teale GR, Nowson CA, Mason RS, McGrath JJ, Thompson MJ, et al. Vitamin D and health in pregnancy, infants, children and adolescents in Australia and New Zealand: a position statement. The Medical journal of Australia. 2013;198(3):142-3.

21. Shaw NJ, Mughal MZ. Vitamin D and child health Part 1 (skeletal aspects). Archives of disease in childhood. 2013.

22. Gordon CM, Feldman HA, Sinclair L, Williams AL, Kleinman PK, Perez-Rossello J, et al. Prevalence of vitamin D deficiency among healthy infants and toddlers. Archives of pediatrics \& adolescent medicine. 2008;162(6):505-12.

23. Yoon JH, Park CS, Seo JY, Choi YS, Ahn YM. Clinical characteristics and prevalence of vitamin D insufficiency in children less than two years of age. Korean journal of pediatrics. 2011;54(7):298-303.
24. Weisberg P, Scanlon KS, Li R, Cogswell ME. Nutritional rickets among children in the United States: review of cases reported between 1986 and 2003. The American journal of clinical nutrition. 2004;80(6 Suppl):1697S-705S.

25. Gallo S, Comeau K, Vanstone C, Agellon S, Sharma A, Jones G, et al. Effect of different dosages of oral vitamin $\mathrm{D}$ supplementation on vitamin D status in healthy, breastfed infants: a randomized trial. JAMA : the journal of the American Medical Association. 2013;309(17):178592.

26. Wagner CL, Howard C, Hulsey TC, Lawrence RA, Taylor SN, Will H, et al. Circulating 25-hydroxyvitamin $\mathrm{d}$ levels in fully breastfed infants on oral vitamin $\mathrm{d}$ supplementation. International journal of endocrinology. 2010;2010:235035.

27. Onwuneme C, Carroll A, McCarthy R, Kilbane M, McKenna M, Murphy N, et al. Towards evidence based medicine for paediatricians. Question 2. What is the ideal dose of vitamin D supplementation for term neonates? Archives of disease in childhood. 2012;97(4):387-9.

28. Shakiba M, Sadr S, Nefei Z, MozaffariKhosravi H, Lotfi MH, Bemanian $\mathrm{MH}$. Combination of bolus dose vitamin $\mathrm{D}$ with routine vaccination in infants: a randomised trial. Singapore medical journal. 2010;51(5):440-5.

29. Siafarikas A, Piazena H, Feister U, Bulsara MK, Meffert H, Hesse V. Randomised controlled trial analysing supplementation with 250 versus 500 units of vitamin D3, sun exposure and surrounding 
Vitamin D status in Irish infants.

factors in breastfed infants. Archives of disease in childhood. 2011;96(1):91-5.

30. Holmlund-Suila E, Viljakainen $\mathrm{H}$, Hytinantti T, Lamberg-Allardt C, Andersson S, Makitie O. High-dose vitamin $d$ intervention in infants--effects on vitamin d status, calcium homeostasis, and bone strength. The Journal of clinical endocrinology and metabolism. 2012;97(11):4139-47.

31. Cattaneo A, Burmaz T, Arendt M, Nilsson I, Mikiel-Kostyra K, Kondrate I, et al. Protection, promotion and support of breast-feeding in Europe: progress from 2002 to 2007. Public health nutrition. 2010;13(6):751-9.

32. Executive HS. National Infant Feeding Policy for Maternity and Neonatal Services. ; 2012. p.
33. Breastfeeding inIreland. A Five year strategic action plan. In: Health, editor. 2005.

34. Bartoli F, Martinez JM, Ferrarini A, Recaldini E, Bianchetti MG. Poor adherence to the prophylactic use of vitamin D3 in Switzerland. Journal of pediatric endocrinology \& metabolism : JPEM. 2006;19(3):281-2.

35. Doolan A, Cousins J, Sheridan-Pereira M. Vitamin D supplementation in babies. Opinions of mothers. Irish medical journal. 2012;105(1):2.

36. McSwiney E, Moran P, Garvey A, Quet J, Kelly T, Watson M, et al. Compliance with the HSE policy on vitamin D supplementation for infants. Irish medical journal. 2013;106(3):93. 